\title{
När den goda viljan inte finns. Om frånvarande fäder i kontaktfamiljsinsatsen
}

\author{
MARGARETA REGNÉR
}

\begin{abstract}
Socialtjänstens kontaktfamiljsinsats är ofta nära länkad till frånvarande fäder och umgängesvägran. I diskurserna om den omsorgsgivande fadern och barncentrering kan ensamstående mödrar drabbas av ett litet makt- och handlingsutrymme. Kontaktfamiljsinsatsen kan bidra till emancipation och öka mödrarnas handlingsutrymme.
\end{abstract}

\section{Introduktion}

Artikeln bygger på intervjuer med 17 ensamstående mödrar och är en del av en större studie om insatsen kontaktfamilj, där mödrarna, deras kontaktfamiljer och socialsekreterare intervjuas om bland annat sin syn på familj och föräldraskap. ${ }^{1}$ Mammorna har sökt lösning på sin situation genom socialtjänstens bistånd kontaktfamilj. Den vanligaste orsaken till att detta bistånd beviljas är att fadern saknas som stöd till mor och barn samt att det sociala nätverket i övrigt är svagt (Andersson \& Bangura Arvidsson 2001).

Margareta Regnér, doktorand vid institutionen för socialt arbete, Göteborgs universitet.
Mammorna söker då avlastning från ett konstant och ensamt omsorgstagande om sina barn.

Syftet med denna artikel är att beskriva och analysera ensamstående mammors situation när umgänget mellan far och barn inte fungerar. En central frågeställning är huruvida kontaktfamiljsinsatsen kan fungera som en emancipatorisk kraft för ensamstående mödrar. En annan frågeställning berör vilken roll socialpolitiska ställningstaganden har för ensamstående mödrars föräldraansvar.

1 Se den första rapporten; Johnsson \& Regnér (2003), samt artikeln Regnér \& Johnsson (2006). Studien finansierades av Forskningsrådet för Arbetsliv och Socialvetenskap (FAS). 
Teoretisk bakgrund till artikeln finns bl.a. att söka i Connells (1987) begrepp genusordning, med innebörden att i varje samhälle finns konstruerade mönster av relationer mellan män och kvinnor, samt kulturella föreställningar om dessa mönster. Också begreppet hegemonisk maskulinitet (Connell 1995) är viktigt (här om den omsorgsgivande fadern), då ett av den hegemoniska maskulinitetens viktigaste kännetecken är att det är få män som lever upp till den, men alla förhåller sig till den direkt eller indirekt (se Bekkengen 2003).

Artikeln visar hur socialpolitiska ställningstaganden grundade i diskurser om den omsorgsgivande fadern, jämställdhet och barncentrering paradoxalt nog kan lägga ett tryck på ensamstående mödrar att bära ansvar, inte bara för sina barn, utan också för faderns föräldraansvar. Dessutom visas att fadern genom sitt undandragande av stöd kan utöva makt över moderns handlingsutrymme, inte minst genom att via gemensam vårdnad ha möjlighet att neka modern avlastning.

\section{Bakgrund}

De ensamstående mammorna i studien visade sig ha en syn på familjen som ligger $\mathrm{i}$ linje med modern familjeforskning, dvs. att alla eller inga familjer är normala i dagens samhälle. Men när frågan gäller kraven på kontaktfamiljen vill mammorna gärna att det egna barnet ska få uppleva en whel familj med både en mamma och en pappa» som delar ansvaret för barnen. Mammorna beskriver stor saknad efter den andre föräldern i funktionen av att vara någon att dela både problem och glädjeämnen med runt det gemensamma barnet, även i de fall föräldern är bortvald. »Kontaktföräldrarna" som inte saknar någon att dela föräldraskapet med framhåller på samma sätt sin partner som det viktigaste stödet i föräldraskapet även när tillgång till omfattande annat nätverksstöd finns.

Det är inte bara på individnivå bilden av det gemensamma föräldraskapet betonas utan detta sker också på samhällelig nivå, synliggjort exempelvis via lagstiftning rörande familjerätt (vårdnad, boende och umgänge) och föräldraförsäkring. Föräldrar uppmuntras att gemensamt sköta barnens omsorg antingen de lever tillsammans eller inte, och det förväntas av båda föräldrarna efter en separation att de skall och vill upprätthålla sitt föräldraskap (Hydén \& Hydén 2002). Det gemensamma föräldraskapet efter separation/skilsmässa motiveras utifrån tanken om "barnets bästa", uttolkat i lagstiftningen som att barnets behov av umgänge med båda sina föräldrar är centralt (Regeringsprop. 1997/98:7, SOU 2005:43).

Samhällets förväntan på föräldrar innebär också en kulturellt betonad förstärkning av mödrar och fäder som jämställda, där fäders betydelse i omsorgen om och ansvaret för barnen betonas särskilt. Plantin et al. (2000 s. 40) hävdar att »den svenska diskursen om det nya och aktiva faderskapet blivit hegemonisk, eftersom det inte längre är accepterat att uttrycka några alternativa ståndpunkter, åtminstone inte i det offentliga samtalet« . Den svenska familjepolitikens "normativa grundkoncept« har slagit igenom på alla nivåer i samhället (op. cit.). I praktiken är dock inte jämställdhe- 
ten genomförd ens i familjer med två föräldrar, då hemarbete och primärt ansvar för barnen till största delen tycks vila på mödrarna (Plantin 2003).

Både jämställdhetspolitiken och bilden av den omsorgsgivande fadern kan alltså problematiseras. Elvin-Nowak (2005) menar exempelvis att trots jämställdhetspolitikens beskrivningar av likhet - dvs. att det inte spelar någon roll om en förälder är mamma eller pappa - finns ett särartstilltal från myndigheterna som bygger på att pappor är en annan sort än mammor. Synen på pappan har i myndigheternas tilltal förändrats från att vara en stödperson till mamman till att vara viktig i sig själv. Men till skillnad från mamman (som i tilltalet har moderskapet naturligt) måste han »äras upp« och i detta vädjar man till mannens goda vilja. Elvin-Nowak skriver: „Uppfattningen att verklig jämställdhet bygger på männens goda vilja är väl etablerad i den offentliga jämställdhetsdebatten. Det är också männens goda vilja den offentliga rösten vädjar till när män tilltalas som pappor» (s. 61).

Ett exempel på hur denna offentliga röst kan ta sig uttryck är diskussionen om umgänge i propositionen 1997/98:7 Vårdnad, boende och umgänge. Där diskuteras begreppen "umgängesvägran" (när en förälder undandrar sig umgänge) och »umgängessabotage» (när en förälder barnet bor hos försvårar eller omöjliggör umgänge). Vi vet alla att de flesta som beskrivs vägra umgänge är män och de flesta som beskrivs sabotera umgänge är kvinnor. I propositionen finns diskussioner om betydelsen av handlingssätten och eventuella påföljder mot föräldrar som begår dessa handlingar. I fallet umgängesvägran föreslås inga sanktioner mot föräldern som undandrar sig umgänge med motiveringen att "det finns risk att umgänge som tvingas fram med sanktioner verkar i fel riktning vad gäller relationerna" (s. 62). Bristen på rättsliga lösningar i detta fall kallar Nordborg (1997) ett "rättstomt rum». I fallet umgängessabotage skriver propositionen att det finns "skäl att inta en sträng hållning" (s. 62) med föreslagna sanktioner i form av böter, verkställighet via polis och prövning av vårdnadsfrågan. Att det är föräldrarätten och inte barns rätt som är i fokus, då barn kan tvingas till umgänge men inte hävda rätten till umgänge framhålls t.ex. av Nordborg (op. cit.) och Bergman och Högberg (2002). De sistnämnda slår fast: „Umgängesrätten kan alltså beskrivas som en frivillig aktivitet för föräldern, men en plikt för barnet. Umgängesrätten är inte en barnrätt men en föräldrarätt» (s. 16). De vuxnas sätt att hantera umgänget har dock olika "frivillighetsgrader", då det ena omfattas av hot om tvång och det andra av frivillighet.

Även benämningarna förstärker skillnaden mellan hur olika handlingar ska uppfattas i rättsprocessen - inte som bara vägran respektive hindrande - utan som vägran respektive sabotage. Skillnaden i ordval och i sanktioner kan lätt leda tanken till att det ena beteendet förorsakar mycket större problem för barn än det andra (eller sker i större omfattning), medan det i själva verket handlar om ett särartstilltal baserat på kön. Umgängesrätten har blivit kritiserad och kallats fadersrätt (Nordborg op.cit.). Främst har kritiken framförts i samband med hanteringen av våldsamma

Margareta Regnér: När den goda viljan inte finns. Om frånvarande fäder i kontaktfamiljsinsatsen. 
fäders umgänge (se t.ex. Eriksson 2003).

De problem som kan finnas i situationer av umgängesvägran har dock belysts och engagerat debattörer i mindre omfattning. Trots att majoriteten av alla ensamstående föräldrar delar föräldraskap med barnets andre förälder via umgänge eller växelvis boende, var det fortfarande åren 2000/2001 13 procent av barnen till icke sammanlevande föräldrar som saknade kontakt med den frånlevande föräldern (SCB 2003:1.2) - dvs. drygt 60000 barn. Därtill kommer $16-20$ procent med umgänge mindre än en gång per månad (SCB 2004:1 s. 59).

Det är i den ovan beskrivna kulturella kontexten som de ensamstående mödrarna i den inledningsvis refererade studien lever. De ensamstående mödrar, vars utsagor är grund för denna artikel, beskriver vanligtvis situationer av "umgängesvägran». Insatsen kontaktfamilj och situationen för majoriteten mödrar som brukar den existerar alltså i ett socialpolitiskt fält som sträcker sig utanför barnavårdsåtgärder som ett residualt system, inte minst genom de ovan nämnda socialpolitiska diskurserna. ${ }^{2}$

\section{Metod}

Huvudstudien var en kvalitativ intervjuundersökning. Det strategiska urvalet baserades såväl på typiska fall som på

2 Att tala om t. ex. kontaktfamiljsinsatsen som ett residualt system innebär en tanke om att insatsen ingår i ett system som människor använder först när »egentliga» välfärdsarrangemang inte fungerar (Lundström 2000). variation inom dessa (Patton 2002). Typiska fall valdes bland ensamstående mödrar, då tidigare studier visat att biståndet kontaktfamilj i majoriteten av fall riktats till ensamstående mödrar med svaga nätverk (Andersson 1992, Sundell et al. 1994, Andersson \& Bangura Arvidsson 2001). Fallen insamlades från socialkontor i tre kommuner. Detta för att undvika påverkan av ett enskilt socialkontors bedömningar av lämpliga fall, och/eller att undvika att levnadsomständigheter på en bostadsort skulle få alltför ensidig inverkan på familjesituationen. Jämn könsfördelning samt variation i åldern på barnen eftersträvades för att se om kön och/eller ålder samspelar med vad som är viktigt i föräldraskapet och insatsen. Insatsen borde också ha pågått minst ett år. Utifrån avidentifierade listor på samtliga "kontaktbarn" vid de tre socialkontoren lottades barnen med hänsyn tagen till nämnda urvalskriterier.

18 familjer med ensamstående föräldrar (varav en pappa) med ett eller flera barn kom att delta. De 18 barnen var jämnt fördelade på åldrarna tre till 13 år, åtta flickor och tio pojkar. Samtliga 18 berörda kontaktfamiljer deltog i studien, liksom de nio socialsekreterare som var handläggare i fallen.

Den ensamstående föräldern intervjuades först, därefter kontaktfamilj och socialsekreterare. Tre semistrukturerade frågeformulär med i stort sett identiska frågor till de olika "parterna" användes. Parternas bilder kunde jämföras både i det enskilda "caset" med klientfamilj, kontaktfamilj och socialsekreterare, inom respektive kategori (t.ex. alla kontaktfamiljer) samt mellan kategorierna (alla klientfamiljer jämfört 
med alla kontaktfamiljer osv.). Intervjusituationen uppmuntrade även till fritt berättande. Intervjuerna tog mellan 1,5 och 3 timmar, skrevs ut ordagrant och analyserades därefter. Olika tekniker har använts i analysarbetet, men gemensamt för dem är ett sökande efter mönster och utmärkande egenskaper i materialet (se bl.a. Kvale 1997). Analysarbetet av det material som ligger till grund för denna artikel har gått till på följande sätt: För att finna variation i intervjupersonernas upplevelser var första steget att göra tematiska fallstudier för varje person. Därefter gjordes korsvisa analyser och jämförelser (Patton 2002). Temana baserades bland annat på intervjupersonernas olika nätverksrelationer. Materialet sorterades dessutom kronologiskt utifrån vilken tidsperiod beskrivningarna gällde för att se om talet om en speciell relation (eller dess särdrag) rörde speciella perioder. Materialet till artikeln har växt fram utifrån ett $i$ huvudsak induktivt arbetssätt.

Då de tre parterna har uttalat sig från olika positioner i samma "ärende" genomfördes studien med ett stort etiskt hänsynstagande och utifrån informerat samtycke med garanti om konfidentialitet.

Fokus i denna artikel ligger på de 17 mödrarnas bilder och beskrivningar av barnens bristande umgänge eller frånvaro av umgänge med fadern. Fadern har inte intervjuats. I några fall har detta inte varit möjligt p.g.a. att fäderna var avlidna (två fall), faderskapet inte fastställt (två fall) eller fäderna vistades utanför Europa (två fall). I de resterande elva fallen hade intervjuer med fäderna kunnat öka förståelsen av deras upplevelser och val av handling
- inte minst då flera av de ensamstående mödrarna själva hade svårt att förstå männens handlande. Det hade också kunnat ge en bild av den interpersonella nivån, av hur respektive förälder tolkar och interpunkterar i en samspelsprocess (Watzlawick et al. 1967). Denna artikel baseras alltså på moderns version. Detta liknar också den verklighet mödrarna mestadels beskriver - dvs. bristande eller ingen verbal kommunikation med fadern.

En generell beskrivning av informanterna ger vid handen att de flesta klientmödrarna är mellan 35-39 år (yngst 20 och äldst 44 år). De har ett barn (8), två barn (4), tre barn (3), fyra barn (1) och sju barn (1). Den sociala situationen skiftar: Vissa mödrar yrkesarbetar - någon har aldrig gjort det. Vissa har aldrig haft kontakt med socialtjänsten förut - andra är uppvuxna i familjer där socialtjänsten funnits med under deras egen barndom. Variationen är alltså stor mellan mödrarna men det finns också gemensamma drag: De är lika i bristen på nätverksstöd relaterat till föräldraskapet (t.ex. möjlighet till avlastning), lika $i$ en livssituation av tilltagande isolering under småbarnsåren och de har nästan alla knapp ekonomi. Gemensamt är också att ett ensamt föräldraskap var något man minst av all hade önskat sig (se även Bak 1997).

\section{Parrelationen upphör...}

Ett framträdande mönster i de intervjuade mödrarnas beskrivningar är att möjligheten till ett gemensamt föräldraskap upphörde när parrelationen bröts. Hydén och

Margareta Regnér: När den goda viljan inte finns. Om frånvarande fäder i kontaktfamiljsinsatsen. 
Hydén (2002) menar att föräldrar efter en separation måste rekonstruera sitt föräldraskap så att det skiljs från föräldraskapet inom det tidigare familjeskapet (författarnas begrepp). Att rekonstruktionsprocessen kan vara svår indikeras av att samhället byggt upp en institution för samarbetssamtal, menar Hydén och Hydén. I vår studie är avsaknaden av ett gemensamt föräldraskap efter separation en vanlig utgångspunkt för kontaktfamiljsinsatsen. Vissa mödrar har inte "lyckats" rekonstruera ett gemensamt föräldraskap tillsammans med fadern efter familjeskapet. Andra mödrar som inte tidigare sammanbott med fadern har inte lyckats konstruera ett gemensamt föräldraskap tillsammans med denne, vilket troligen är en väl så svår process.

Inte mindre än tolv av mödrarna blev ensamma i föräldraskapet mycket tidigt, dvs. under graviditeten eller spädbarnstiden och resterande fem när barnen var mellan ett och sex år. Att graviditet och småbarnstid kan vara en tid av ökad stress för alla blivande och nyblivna föräldrar råder det samstämmighet om (se t.ex. Niven 1992). De flesta mödrar förväntar sig stöd av fadern (op.cit.) men för studiens mödrar uteblev det både genom separationen och genom att umgänget inte fungerade. Beskrivningarna ger ibland en bild av ett liv i kris under lång tid, där det ensamma föräldraskapet har gjort det svårt att bearbeta både separationen och upplevelsen av svek i det gemensamma föräldraskapet.

Trots det önskar de flesta mödrarna att barnen ska träffa fadern regelbundet. Bland de nio som tidigare levt med fadern är det endast en som verkar vara nöjd med att fadern inte har kontakt med barnet; detta p.g.a. hans missbruk. ${ }^{3}$ Bland de åtta mödrar som inte levt med barnens far önskar tre att pappan har kontakt med barnet. Tre verkar vara nöjda med utebliven kontakt och i två fall är faderskapet inte fastställt. Detta betyder inte att de är nöjda med situationen eller inte skulle ha önskat en annorlunda situation.

Umgängesvägran eller restriktioner från männens sida och önskat umgänge från kvinnornas sida ger intryck av att vara reversibla enheter. Där vägran finns, finns också önskan; eller är det tvärtom? Flera av mödrarna kan också se fördelar i att ha sluppit förhandlingar med barnets far, en uppfattning som förstärks av de bilder som andra ensamstående föräldrar förmedlar. Men när de tänker på barnet är den övervägande bilden frustration över faderns bristande deltagande i barnets liv.

\section{Umgänge - inte umgänge, några exempel}

Nedan följer exempel på hur varierande berättelser om fäders kontakt eller brist på kontakt med barnen kan gestalta sig och upplevas av mödrarna. Det första exemplet beskriver och diskuterar detta mer utförligt än de övriga.

3 Mödrar som tidigare har bott ihop med fadern är nio. Men vid intervjutillfället är två av fäderna avlidna. I det ena fallet avled fadern inom äktenskapet när barnet var ett par månader. I det andra fallet avled fadern efter föräldrarnas skilsmässa och några månader före intervjun. Här förekom ingen kontakt mellan far och barn före dödsfallet. 


\section{A) Från inget umgänge till regelbundet umgänge, en historia om besvikelser, svek och tillitsbrist}

En mamma (2) beskriver hur ett umgänge mellan far och barn påbörjades först när barnet var sex år. Vid intervjun hade kontakten varat ett år och uppgick till ett par timmar varannan vecka. Barnet hade innan dess aldrig träffat sin pappa. Följande är ett sammandrag av mammans beskrivning av hur hon upplevt situationen och hur umgänget startade.

Mamman berättar att hon var sambo med pappan i tre år. Pappan inledde ett nytt förhaillande samtidigt som hon själv blev gravid. "Det var mitt första längre förhållande där jag blev bränd", säger hon. Utifrän denna erfarenhet har hon valt distans $i$ ett par senare förhållanden. Hon tycker att hon borde ha kommit över det men "det var tunga erfarenheter". När barnet var ca sex år flyttade pappan med sin nya partner och deras barn till samma bostadsområde som mamman och barnet bodde i. De stötte ihop med pappan på gatorna (barnet ovetandes). Mamman berättar att barnet samtidigt började tilltala främmande män med frågan: "Är du min pappa?" Detta gjorde att mamman konfronterade pappan med hans avsikter. Hon säger att pappan ville lära känna sitt barn och bli hans far. Innan fanns "de sex intensiva åren där jag inte haft en timme för mig själv ... ja, det är en sådan trötthet som jag känner". Hon "mådde dåligt" av att pappan hade flyttat till området, då han har "en pojke till då som han fanns för ". Mamman har känt en förlust $i$ att pappan inte var med frän början och missat och saknat att tala med pappan om barnet. Även idag har mamman svärt att lita på pappan men tror ändå att "han känner genuint" för sonen. Men hon är tryggare när barnet är $i$ kontaktfamiljen än de få timmarna han är hos pappan. Umgänget höll en period på "att krascha" och hon kände: "Ska det bli det totala sveket här nu? Att han efter att ha visat sig försvinner igen? Då är det det optimala! Det skulle nog göra mycket mer ont och sätta djupare spår". Mamman säger dock att "mycket har hänt om man jämför med ett år tillbaka" då kontaktfamiljen kom in samtidigt som fadern dök upp och att denne och sonen numera har en regelbunden kontakt. Umgänget försiggår dock wutifrån ickekommunikation", säger hon, och hon hade önskat ett bekräftande samtal på morgonen de dagar pappan hämtar sonen på fritids. $\mathrm{O} m$ den tidigare parrelationen säger hon: "Allting som finns där mellan oss är fortfarande ouppklarat $i$ och med att brytningen var så total och ingenting har egentligen klarats ut. Så har ju vi oerhört mycket som ligger under ytan bara".

Det är påfallande genom intervjun, vilket mamman också uttrycker, hur de initiala problemen i samband med separationen levt kvar mentalt samt hur temat om svek och bristen på tillit finns med i beskrivningen av olika faser av hennes och barnets livssituation. Efter ett år av kontakt mellan far och son kände sig mamman fortfarande tryggare när barnet var i kontaktfamiljen än hos pappan, då rädslan för nya svek finns kvar. Även om talet om »svek» verkar gälla barnet, finns många exempel i intervjun på

Margareta Regnér: När den goda viljan inte finns. Om frånvarande fäder i kontaktfamiljsinsatsen. 
att det också gäller mamman själv. Denna gräns är kanske inte alltid lätt att dra. Också möjligheten att bearbeta vad som i fallet ovan skulle kunna kallas »kris», påverkas givetvis av livssituationen. Att mannen drog sig ur den påbörjade familjebildningen och bröt kontakten helt, verkar ha gjort det särskilt svårt för kvinnan att fullgöra separationen på egen hand. Dessutom fungerar antagligen alla de svårigheter ett isolerat föräldraskap för med sig som extra påminnelser om mannens frånvaro, vilket bidrar till att han blir mentalt närvarande i hennes liv. Som flera andra föräldrar hade dock denna mamma i det längsta försökt att klara sig själv innan hon ansökte om kontaktfamilj.

Föräldrarna i vår undersökning beskriver - liksom kvinnan ovan - hur de innan kontaktfamiljsinsatsen saknat egen tid utan barn, i brist på avlastande nätverk. Detta kan bidra till att upplevelsen av svek förstärks. Det finns ingen annan nätverksperson som en mamma rimligen skulle kunna förvänta sig samma stöd av runt barnet som av pappan. Den tid mammorna delar med sitt barn innebär ett mycket intensivt liv. De talar om hur de fått vara »både mamma och pappa», liksom "en 150 procent förälder». Att exempelvis alltid ha med barnen i tvättstugan eller till affären, liksom att inte ha avlastning ens vid egen sjukdom är konkreta beskrivningar. Weiss, refererad i Gähler (1998), talar om »task-overload» som svårigheten att ta hand om alla uppgifter den ensamstående mamman både kräver av sig själv liksom blir avkrävd i omgivningen. Utan en annan vuxen i hushållet måste mamman dessutom vara tillgänglig hela tiden, då många av barnets behov eller krav från barnen inte går att skjuta upp eller negligera (op.cit.).

En ytterligare tolkning av exemplet ovan är att svårigheterna i den ensamma livssituationen väcks till liv när barnets far visar sig med både den nya kvinnan och det nya barnet som "han finns för". I intervjun finns bilder av saknad av en far som ger barnet omsorg men också som någon modern kan dela föräldraskapet med. Konstruktionen av ett gemensamt föräldraskap har i detta fall efter sju år möjligen påbörjats. Varför pappan har hållit sig undan i sex år har mamman ingen förklaring till - utom detta att hennes graviditet sammanföll med att det andra förhållandet etablerades.

Mamman visar ingen tendens till att ifrågasätta eller hindra umgänget. Trots oro för nya besvikelser är hon övertygad om vikten av barnets kontakt med sin far. Det är också hennes uppgift i lagens mening, då föräldrars aktiva medverkan till den andre partens umgänge är en fråga som avgör om man är lämplig som vårdnadshavare. Någon bortre tidsgräns för hur länge den kvarvarande föräldern skall ha beredskap för den andre förälderns deltagande i umgänget finns inte i lagstiftningen. Även om en sådan formaliserad tidsgräns skulle vara svår att realisera ställer detta krav på modern. Hon ska klara av att - kanske under en lång tid - ställa in sig på ett föräldraskap utan fadern, parallellt med kravet att eventuellt - om fadern vill - delta i konstruktionen av ett gemensamt föräldraskap. Med andra ord ställs det mycket stora krav på anpassning hos modern. 


\section{B) Oregelbundet umgänge - att skapa en far?}

En mamma (17) som inte tidigare bott med barnets far beskriver ett oregelbundet umgänge som har börjat öka i omfattning. Pappan beskrivs av mamman som negativ till kontaktfamiljsinsatsen. Ett sammandrag:

Mamman märkte tidigt att den blivande pappan inte ville flytta ihop. Men han ville gärna ha barn, säger hon. De pratade mycket om hur det skulle fungera om parrelationen tog slut och pappan lovade "att vara pappa till 100 procent". Mamman hade samtidigt upplevt en mycket traumatisk händelse och var väldigt noga med att få veta att jag inte skulle bli ensam med barnet för jag kände mig svag. Annars var hon osäker på om hon skulle behälla barnet, säger hon. Pappan sökte jobb utomlands och for när pojken var ett par månader. Han skulle vistas hemma regelbundet, men så har det inte blivit. Han var hemma utan att höra av sig och har talat om att flytta utomlands. Mamman vet aldrig när han kommer hem: "Han säger t.ex. att han ska komma hem 8 maj och så kommer han 8 augusti", säger hon. "Jag vet inte var jag har honom". På senare tid har de dock kunnat tala om scheman på en familjemottagning. Mamman saknar att ha fätt dela pojkens utveckling med pappan, men tror inte på kärnfamiljen. Då hon inte vill att barnet ska ha föräldrar som hatar varandra, säger hon waldrig ett ont ord om pappan, fast jag skulle kunna, för jag tycker han har varit vidrig". Istället säger hon att pappan tycker om pojken och »ljuger och säger att han längtar efter pojken men det vet jag inte om han gör". Hon pratar ofta om pappan för att pojken inte ska glömma honom och kommenterar detta: "Såtror jag att jag är bra faktiskt. När jag jämför med några andra kan jag säga att jag verkligen jobbar med det här". Men hon kommer aldrig att kunna lita på pappan sedan han lovade att vara pappa till 100 procent för hon litade på honom då. Idag, när pojken är fem år, har pappan vistats mer hemma och för första gången har pojken sovit över hos honom. Mamman ser att pappan är förtjust i pojken och är glad för det.

Denna mamma ställde redan under graviditeten in sig på att parrelationen skulle upphöra. Föräldrarna kommunicerade tidigt om hur ett gemensamt föräldraskap utanför parrelationen skulle konstrueras. De överenskommelser mamman beskriver handlar om ett gemensamt föräldraskap med en omsorgsgivande far, då mamman på förhand oroade sig för att inte klara föräldraskapet ensam. Kanske är konstruktionen av ett gemensamt föräldraskap påbörjat efter fem år. Mamman skildrar i övrigt i intervjun en mycket svår situation i det ensamma föräldraskapet utan några släktingar på orten. Trots detta ser hon det som sin uppgift att hålla pappan vid liv hos barnet på ett positivt sätt. Också här finns upplevt svek som tema samtidigt med ett stort ansvarstagande för relationen mellan far och son. Mammans övertygelse om vikten av pojkens kontakt med fadern är orubblig.

Margareta Regnér: När den goda viljan inte finns. Om frånvarande fäder i kontaktfamiljsinsatsen. 


\section{C) Inget umgänge - pappa medfjärrkontroll}

I två fall har pappan förutom kontaktbarnet också två äldre barn med samma mamma. I båda fallen har pappan umgåtts med de äldre barnen efter separationen (dock mycket oregelbundet), men har vägrat kontakt med det barn (kontaktbarnet) som avlats i samband med separationen. Separationen har (som i fall A ovan) skett i samband med att en ny relation etablerats. Båda dessa mammor beskriver också hur pappan - trots sin ovilja till umgänge med barnet - har haft synpunkter på kontaktfamiljsinsatsen för barnet (se även fall B ovan). I det ena fallet (11) har pappan villkorat vem som skulle vara kontaktfamilj och i det andra fallet (16) har pappan nekat modern kontaktfamilj med motiveringen att han själv skulle umgås med barnet, vilket sedan aldrig skedde. Strax före sin död godtog pappan att barnet skulle få vistas i kontaktfamilj. Mamman säger: »Det är karlars makt det".

Den första mamman (där fadern villkorat kontaktfamiljen) beskriver hur det oregelbundna umgänget med syskonen till kontaktbarnet och faderns vägran att umgås med kontaktbarnet påverkat henne:

Pappan pluggar påannan ort men mamman anser att hon vet att han är oftare hemma än han säger. Hon säger: "Jag har bett honom att vi ska säga en helg varje månad eller en helg varannan månad. Då hade jag åtminstone en helg varannan månad som jag visste och kunde planera saker, men han går inte med på det«. Hon vet inte förrän kvällen innan om umgänget kommer till stånd och även när det varit mer regelbundet är det bara ett tag framöver. Hon vet inte när regelbundenheten tar slut. Att pappan inte tagit barnen regelbundet har gjort att mamman är sjukskriven 25 procent nu, menar hon. Mamman uppger att 5-åringen träffat fadern sammanlagt fem timmar $i$ sitt liv. Hon har också bett pappan att träffa de äldre barnen då kontaktbarnet är i kontaktfamiljen, men har inte fätt svar. Även socialsekreteraren beskriver hur hon har gätt bet i sina försök att diskutera med pappan.

Brist på kontroll präglar denna mammas beskrivning av sin situation före kontaktfamiljsinsatsen. Också $i$ andra fall där fäderna umgås oregelbundet finns denna bild (se t.ex. B ovan). För att få regelbundenhet och framförhållning har hon haft låga krav på umgängets intensitet. Att situationer med bristande förutsägbarhet och kontroll är stressframkallande vet vi från annan forskning (Antonovsky 1991, Sapolsky 2003). Mamman säger sig också ha blivit sjukskriven på grund av detta. Hon förstår inte mannens motiv till att han inte vill umgås med det yngsta barnet och inte heller förstår hans släktingar varför.

Ingen av de två beskrivna fäderna vill umgås med barnen eller delta i omvårdnaden men har ändå synpunkter på kontaktfamiljsinsatsen. Att känna till mammans problem med avlastning och inte försöka underlätta för henne, samt själv neka att ta sitt ansvar, kan inte ses som annat än utövande av kontroll och inflytande över en relation man tidigare valt bort. 


\section{D) Inget umgänge-en far man helst inte talar om}

Det finns också mammor som inte uttrycker någon önskan om att ett umgänge kommer till stånd. En mamma (1) säger rent ut att fadern är olämplig och hos tre andra $(5,10$, 18) kan man ana det, när de talar knapphändigt eller inte alls om fadern. Den första säger kortfattat om pappan: „Han är missbrukare, så därav den mycket sporadiska kontakten (...) Den är i stort sett obefintligu. Hon ville att kontaktfamiljen skulle vara en kärnfamilj för att barnet skulle »få se att det finns fäder som ställer upp för sin familjк. Det finns ingen beskriven önskan eller saknad av ett delat föräldraskap $i$ intervjun, men hon vill att barnet ska få del av en sådan möjlig erfarenhet. En annan mamma bad socialsekreteraren att inte kontakta pappan när hon sökte kontaktfamiljsinsatsen, vilket respekterades. Men hon avvisar inte umgänge eller delat föräldraskap generellt, då ett syskon till kontaktbarnet umgås med sin far och den nye mannen beskrivs som en pappa till kontaktbarnet.

Intressant är att ingen av mammorna som beskriver fadern mycket knapphändigt ger någon bild av att barnen intresserar sig för ett umgänge med pappan eller av att få veta mer om honom, vilket de övriga gör. Det finns inget resonemang om barnets behov av att känna till sitt ursprung. Föräldrarna är nöjda med att kontakten inte finns. Det starka (tysta) trycket av att mammorna inte vill orda om pappan har känts av även i intervjusituationen och verkar också ha accepterats av socialtjänsten. Detta att barnen inte heller beskrivs ha frågat om sin far skulle kunna tolkas som att detta "sche- matryck" (se Bernler \& Johnsson 2002) gör att såväl intervjuaren, socialtjänsten som barnen avstår från att fråga vidare om dessa fäder. Huruvida kvinnornas strategi innebär "umgängessabotage" går inte att uttala sig om - klart är dock att de inte heller lever med en förväntan på barnets far om ett delat föräldraskap. Kvinnornas knapphändiga tal om fadern kan tolkas som att relationen för kvinnan ses som ett eget misslyckande och/eller som att fadern skulle utgöra en olämplig förebild. Men man kan också tolka det som att denna strategi gör att kvinnorna slipper de problem det skulle kunna innebära med en aktiverad faderskontakt. Genom att barnen inte tycks efterfråga fadern (och fadern inte barnen) slipper kvinnorna det samhälleliga trycket på barns rätt att umgås med båda sina föräldrar. Om en förälder vill slippa ett sådant umgänge är kanske en sådan förtigandets strategi enda utvägen?

\section{E) Inget umgänge - den "kränkte"fadern?}

Två mammor har svårt att förstå sig på pappan som avvisar kontakt men de tror båda att orsaken ligger $i$ att de själva tagit initiativ till separationen under graviditeten respektive när barnet var nyfött; dvs. att mannen känt sig »kränkt». Deras önskan är att barnet får kontakt med pappan som identifikationsobjekt. Ingen av dem har levt med pappan. Den ena mamman (4) beskriver hur hon kontaktar pappan ideligen men han vill inte ha med henne att göra. Hon menar ändå att det framför allt var han som inte kunde tänka sig abort. Själv hade

Margareta Regnér: När den goda viljan inte finns. Om frånvarande fäder i kontaktfamiljsinsatsen. 
hon aldrig innan tänkt på att skaffa barn, använde spiral och hade »inte hållit i en bebis». Hon är nöjd med det egna föräldraskapet och väntar sig inte ett gemensamt föräldraskap men vill att barnet, som vid intervjun var fem år, ska få veta vem pappan är. Hon säger:

"Så när jag var i 5:e månaden, då så delade vi på oss totalt... och det har han ju inte kunnat glömma. Så han är ju rätt bitter och jättearg. Så det är därför han inte vill ha med barnet att göra. Antar jag... (...) Men jag kontaktar honom ideligen, ideligen. (Men han vill inte?) Nej han vill inte prata med mig. Nej, jag har jagat honom se'n barnet var ett air och skickat kort och brev och bett honom att ta sitt ansvar. Han vill inte ha med mig att göra. Och jag väntar mig inte heller att han ska fungera som nå'n avlastning utan jag är ute efter att barnet ska få veta vem pappan är. Och få en bild av honom».

Den andra mamman (8) har sökt kontakt med pappan via barnets farmor men tyvärr, säger hon, är han inte intresserad. När hon hade förklarat för pappan att han »hade med barnet men inte med mig att göra" sa han att han ville vara ifred ett tag. Hon säger:

„Visst, jag kan förstå om han blev besviken, men att låta det gå sju år... Man måste ju vara intresserad av kött och blod, tänkte jag. Att man ... kommer över det som hänt och förstår skillnaden att det har med barnet att göra».

Av en händelse träffade intervjuaren senare denna mamma och fick veta att barnet vid tio års ålder hade börjat träffa sin far regelbundet en weekend varannan vecka. Pappan levde i en ny relation och mamman beskrev en för henne svår situation. Hon frågade sig: "Hur hämtar man igen de tio åren? "Och hon menade att hennes känsla fortfarande var att hon var ensam ansvarig för barnet.

Båda mammorna håller pappan vid liv $\mathrm{i}$ barnens liv och har sökt kontakt upprepade gånger utan resultat. Ingen av dem har förväntningar på ett delat föräldraskap, utan snarare på ett parallellt föräldraskap, dvs. en far som har kontakt med sitt barn men inte är ett stöd för modern (Bak 1997). Inte ens detta har de vid intervjutillfället lyckats uppnå. Båda är dock redo att ta emot fadern om han ändrar sig, precis som samhället förväntar av dem och en konstruktion av ett gemensamt föräldraskap har i det ena fallet påbörjats efter tio år.

\section{Kontaktfamiljsinsatsen som emancipatoriskt stöd}

Trots ovanstående bilder är flera mammor nöjda med sitt eget föräldraskap, utom i vissa avseenden som t.ex. att vara tillräckligt konsekventa och att sätta gränser för barnen (se Johnsson \& Regnér 2003). De har samtliga tagit sig an ensamansvaret (utan annat nätverksstöd) för barnen. Majoriteten av kvinnorna tar också ansvar för att barnen ska få träffa eller ha kontakt med sin far. I den mån detta inte lyckas har några mammor haft förväntningar om kompletterande faders- eller mansbilder i kontaktfamiljen. Men huvudskälet till kontaktfamiljsinsatsen är behovet av egen 
(regelbunden) avlastning. Insatsen har i detta avseende av de flesta upplevts som en oerhörd hjälp: "Jag kunde aldrig tro att det skulle hjälpa mig så mycket", säger en mamma vars barn är i kontaktfamiljen en gång i månaden (Fall C, 11 ovan). Flera är vittnesmålen om att "det hade inte gått annars». Att inte orka med föräldraskapet ger dock bilden av det egna moderskapet en kraftig törn. Att besluta sig för att ansöka om kontaktfamilj är därför ofta svårt. Därefter kan själva ansökningsprocessen upplevas stigmatiserande. En mamma säger:

"Att gå igenom utredningarna till att få lov att ansöka om det här bidraget var väldigt utlämnande. Bland det värsta jag har gjort. Jag har aldrig suttit i den situationen att jag behövt lämna ut mig på det sättet innan».

Retrospektivt framhåller dock såväl denna som andra mammor att det inneburit en styrka att ha klarat av att söka hjälp. Det var en väg bort ur orimliga krav på det egna moderskapet, som före insatsen av flera beskrivs som att härda ut, att överleva. »Jag skulle sökt det mycket tidigare» är ett vanligt uttalande.

Det är inte mindre än sex fäder som har reservationer mot kontaktfamiljinsatsen (fem bland de tidigare sammanboende och en bland de andra). En tolkning är - trots att papporna avstår från kontakt med barnet eller sköter denna sporadiskt - att de upplever insatsen som en kränkning av fadersrätten. Vid gemensam vårdnad - som normalfallet är idag - kan de också avgöra om mamman ska få avlastning. De kan alltså utan att aktivt delta i föräldraskapet kontrollera och utöva makt över den ensam- stående mamman, som utan annat stöd blir bunden till hem och barn.

Nordborg (op.cit.) menar att gemensam vårdnad och förstärkt umgängesrätt innebär att faderskapet ersätter äktenskapet som den "institution" som kan ge mannen makt över både mor och barn. I några fall ger beskrivningarna även intryck av en bestraffning av modern för att hon bryter parrelationen (och tolkas så av mammorna, se t.ex. E, 4 och 8 ovan). En mamma (13) säger exempelvis att hon "mår dåligt av att papporna inte tar sin del av barnen«, och fortsätter:

„Det är nästan det jag tycker är värst $i$ mitt liv idag. Det är inte för min skull, men ändå är det som att papporna ska straffa mig. Det har de lyckats göra, men de har också straffat barnen och det har sårat mig allra mest".

En motbild mot dessa beskrivningar är att kontaktfamiljsinsatsen har inneburit att mammorna inte behöver vara utlämnade till godtycke när det gäller umgänge och avlastning.

Liljeström och Kollind beskrev redan 1990 förändringen av kvinnornas familjeposition i samhället. De menade att förutom rollerna maka och mor, har moderna kvinnor också rollen som försörjare, medborgare och individer med egen tid. Kvinnor har idag "tillgång till egna, från familjen avskilda livsvärldarı, sade de (s. 13). Kontaktfamiljsinsatsen kan tillerkänna också mödrar som inte har avlastning rätt till egen tid (utöver arbetstiden), vilket för studiens mödrar framstod som utopiskt innan insatsen.

Dessutom beskriver några mammor vad 
som kan tolkas som frigörelse ur ett mentalt underläge: En mamma (se B, 17 ovan) beskriver hur pappan nu är hemma och umgås mer med barnet, men pappan tycker det är fel att mamman har kontaktfamilj, "vilket är ett otroligt dumt uttalande», säger hon. Hon säger att pappan är irriterad över att barnet ska vara i kontaktfamiljen kommande helg istället för med honom och tilllägger: "vi kan ju inte anpassa efter när hans pappa behagar dyka upp», och menar att "det måste ju vara kontinuitet».

I det fall där inget umgänge med kontaktbarnet och endast ett oregelbundet umgänge med de äldre barnen fanns (se C, 11 ovan), berättar mamman på liknande sätt hur hon efter kontaktfamiljsinsatsen har vant sig vid oregelbundenheten och planerar nu som om fadern inte skulle ha barnen. Passar det inte henne får han inte träffa dem »för jag kan inte hänga upp mitt liv på att han ska höra av sig. Jag har kommit så långt nu efter fem årı.

Det finns ibland farhågor bland socialsekreterarna att kontaktfamiljsinsatsen skulle motverka faderns möjlighet till deltagande runt barnet, en tanke som verkar bygga på bilden av fadern som icke handlingskraftig. Bangura Arvidsson (2003) menar i sin avhandling att socialsekreterare ser fäder som "offer«: "Socialsekreterarna förväntar sig att fäder vill vara delaktiga, men att de måste stödjas, 'peppas', och hjälpas i sin fadersroll eftersom den inte uppfattas falla sig lika naturligt som modersrollen gör» (s. 283).

Ett resultat av denna studie är att en förändring mot ökat umgänge har inletts genom att mammorna (ofta via kontaktfamiljsinsatsen) har blivit starkare och brutit sig ur den förlamning som den tidigare isoleringen och den bristande kontrollen innebar. En mamma (7) säger som förklaring till att umgänget har ökat att både pappan och hon själv har ändrat sig: "Han har mognat och jag själv har blivit starkare och mer bestämd». Insatsen har gett mödrarna större oberoende och styrka och därmed bidragit till ett bättre förhandlingsläge eftersom de inte behöver pappans stöd på samma sätt längre.

\section{Slutord}

I de intervjuer som är underlag för denna artikel beskrivs mestadels hur fäder släpper kontakten med sina barn när parrelationen bryts. En tolkning i linje med Castells (1998) är att männen var mer intresserade av kvinnan än av barnet. Det är i flertalet fall främst mödrarna som håller fast vid faderskapets betydelse. De kan ibland i flera år ha beredskap och förhoppningar om att fadern ska ta sitt ansvar - trots hans oförutsägbarhet och bristande stöd (se även Bak 1997). Att det dessutom är mödrarna som tar på sig ansvaret för kontakten mellan far och barn tycks anses vara helt i sin ordning. Även om de säger sig oroa sig mest för barnens skull, innebär bristen på avlastning en upplevelse av egna nederlag i föräldrarollen och känslan av svek - även mot kvinnan själv - förstärks. Diskursen om den aktive och omsorgsgivande fadern tycks vara så stark att mödrarna ofta är oförstående inför faderns agerande.

Att tolka pappans agerande utan att ha hans bild kan vara tveksamt. Men studien visar att även frånvaro av stöd paradoxalt 
nog kan ha funktionen av att mannen håller kvar kontrollen (makt) över mamman. Det innebär att föräldrarna deltar i ett förlängt destruktivt samspel som blir speciellt destruktivt för mamman och barnet, vilket min studie synliggjort.

Många studier visar att om män formar ett omsorgsgivande föräldraskap sker det utifrån en valfrihet (Plantin 2003). Även de mest jämställda männen »drar fördelar av de övergripande patriarkala maktstrukturerna i samhället», hävdar Plantin (s. 155).

Mäns valfrihet och handlingsutrymme symboliseras tydligt i denna studie liksom hur dessa diskurser kan få kvinnor att ställa in sig på ett litet handlingsutrymme. Att begära jämställdhet kan dessutom enligt Bekkengen (2003) ses som ett hot mot barnets bästa. Studiens mödrar saknar inte heller skuldkänslor inför barnen när de ansöker om kontaktfamilj.

I propositionen 1997/98:7 finns en tendens till att se fadern som maktlös. Fadern ska lockas in i sitt ansvarstagande och förväntas inte naturligt ta sin plats. Om han lockas, peppas och lärs upp antar man att "den goda viljan« kan växa fram. Ett sådant synsätt leder till att kvinnor i den situation, som våra informanter beskriver, ensamma får ta konsekvenserna av föräldraskapet liksom ensamma får bära ansvaret för barnets behov av umgänge med den andre föräldern.

Men bilden av den maktlöse fadern kan starkt ifrågasättas och ger en vrångbild när det gäller umgängesvägrande fäder, menar jag. Denna studie visar att det snarare är mödrar och barn som löper risk att bli maktlösa vid umgängesvägran. Kontaktfamiljsinsatsen kan dock medverka till förändring av detta mönster. Mödrar kan genom kontaktfamiljsinsatsen minska sin utsatthet och sitt beroende. När de dessutom upplever mer egenmakt och visar sitt oberoende, tycks vissa fäder i större utsträckning vilja ta sitt fadersansvar.

I rapporten Ensamma föräldrar och vanliga familjer (Johnsson \& Regnér 2003) föreslogs att kontaktfamiljinsatsen skulle bli en samhällelig tjänst för föräldrar som saknar stödjande nätverk. Förslaget byggde på insikten från vår studie om ensamstående föräldrar som under småbarnsåren lever sitt liv under svåra förhållanden och under tilltagande isolering. Det är viktigt att föräldrar som söker hjälp inom socialtjänsten får stöd i att klara sin uppgift "här och nu" som Andersson och Bangura Arvidsson (2001) säger. Kontaktfamiljinsatsen kan medverka till att bryta den isolering och den utsatthet mödrarna beskriver, men insatsen bidrar också till att de kan börja förändra sitt handlingsutrymme i förhållande till faderns utrymme och bli mer bestämda. Detta verkar även kunna leda till att umgänget förbättras och kan därmed förhoppningsvis komma barnen tillgodo. 


\section{Referenser}

Andersson, G. (1992) STÖD och AVLASTNING. Om insatsen kontaktperson/-familj. Lunds universitet: Meddelanden från socialhögskolan 1992:2.

Andersson, G. \& Bangura Arvidsson, M. (2001) Vad vet vi om insatsen kontaktfamilj? En kunskapsöversikt. Lunds universitet: Meddelanden från socialhögskolan 2001:1.

Antonovsky, A. (1991) Hälsans mysterium. Stockholm: Natur \& Kultur.

Bak, M. (1997) Enemorfamilien. København: Forlaget Sociologi.

Bangura Arvidsson, M. (2003) Ifrågasatta fäder. Olika bilder av fäder till socialt utsatta barn. Lund: Dissertations in Social Work 13.

Bekkengen, L. (2003) „Föräldralediga män och barnorienterad maskulinitet». I Johansson, T. \& Kousmanen, J. (Red.) (2003) Manlighetens många ansikten - fäder, feminister, frisörer och andra män. Malmö: Liber.

Bergman, E. \& Högberg, C. (2002). »Inrätta barndomstolar!" Socialpolitik. nr 1, s. 16-17.

Bernler, G. \& Johnsson, L. (2002) Teori för psykosocialt arbete. Stockholm: Natur \& Kultur.

Castells, M. (1998) Informationsåldern. Ekonomi, samhälle och kultur. Band II. Identitetens makt. Göteborg: Daidalos.

Connell, R. W. (1987) Gender and Power. Cambridge: Polity Press.

Connell, R. W. (1995) Masculinities. Cambridge: Polity Press.

Elwin-Nowak, Y. (2005) „Den som passar bäst gör mest - Sammanställning och analys av forskning om föräldrars föreställningar och attityder kring föräldraledighet». I Reformerad föräldraförsäkring - Kärlek, Omvårdnad, Trygghet SOU 2005:73, bil. 3.

Eriksson, M. (2003) I skuggan av pappa. Familjerätten och hanteringen av fäders våld. Stehag: Förlags AB Gondolin.

Gähler, M. (1998) Life After Divorce. Economic, social and psychological well-being among Swedish adults and children following family dissolution. Stockholm University: Doctoral dis- sertation, Department of Sociology. Swedish Institute for Social research 32.

Hydén, M. \& Hydén, L-C. (2002) Samtal om den nya familjen och det eviga föräldraskapet. Stockholm: Natur \& Kultur.

Johnsson, L. \& Regnér, M. (2003) Ensamma föräldrar och vanliga familjer. En studie av insatsen kontaktfamilj inom socialtjänsten. Göteborgs universitet: Institutionen för socialt arbete. Skriftserien 2003: 8.

Kvale, S. (1997) Den kvalitativa forskningsintervjun. Lund: Studentlitteratur.

Liljeström, R. \& Kollind, A-K. (1990) Kärleksliv och föräldraskap. Stockholm: Carlsson Bokförlag.

Lundström, T. (2000) „Om kommunernas sociala barnavård«. I Szebehely, M (red.) Välfärd, vård och omsorg. Antologi/Kommittén Välfärdsbokslut 2000:38.

Niven, C. A. (1992) Psychlogical Care for Families: Before, During and After Birth. Oxford: Butterworth-Heinemann Ltd.

Nordborg, G. (1997) "Om juridikens kön«. I Nordborg, G (red.) Makt \& kön. Tretton bidrag till feministisk kunskap. Stockholm/Stehag: Symposion.

Patton, M. Q. (2002). Qualitative research \& evaluation metods, 3rd ed. Thousand Oaks, London, New Delhi: Sage.

Plantin L, Månsson S-A \& Kearney J (2000) „Mäns föräldraskap. Om faderskap och manlighet i Sverige och England«. Socialvetenskaplig tidskrift nr 1-2, s. 24-42.

Plantin, L. (2003) "Faderskap i retorik och praktik». I Bäck-Wiklund, M. \& Johansson, T. (red.) (2003) Nätverksfamiljen. Stockholm: Natur \& Kultur.

Regeringens proposition 1997/98:7 Vårdnad, boende och umgänge.

Regnér, M. \& Johnsson, L. (2006) „Ensamma föräldrar och vanliga familjer - om familjen som hjälpresurs i socialt arbete». Nordisk Socialt Arbeidnr 2, s. 98-109.

Sapolsky, R. M. (2003) Varför zebror inte fär 
magsår. Om stress, stressrelaterade sjukdomar och konsten att handskas med riskerna. Stockholm: Natur \& Kultur.

SOU (2005) Vårdnad-boende-umgänge. Barnets bästa, föräldrars ansvar. Betänkande av 2002 års vårdnadskommitté. Stockholm SOU 2005:43.

Statistiska Centralbyrån, SCB (2003) BARN och deras familjer 2001. Del 2: Texter och diagram. SCB: Demografiska rapporter 2003 1:2.

Statistiska Centralbyrån, SCB (2004) Barnens tid med föräldrarna. SCB: Demografiska rapporter
2004:1.

Sundell K., Humlesjö E. \& Carlsson M. (1994) Att hjälpa sin nästa. En undersökning av kontaktfamiljer i Stockholm. Stockholms socialtjänst: FOU-rapport 1994:15.

Watzlawick P, Beavin J H \& Jackson D D (1967) Pragmatics of Human Communication. A Study of Interactional Patterns, Pathologies, and Paradoxes. New York. London: W.W. Norton \& Company.

\section{Summary}

\section{When best intentions are non-existent: About absent fathers in the contact family service}

The aim of this article is to describe and analyse the situation for single mothers, whose children have no, negligible or irregular contact with their fathers. The article relies on 17 in-depth interviews with single mothers and is a part of a broader study concerning "the contact family servicew. Mothers, contact families and social workers that handled the cases were interviewed, among other things about their notions of family and parenthood. Single mothers attempt to find a solution to their situation through the service. The most common reason for the service to be provided is the father's lack of support to mother and children, together with scarce social networks as a whole. The mother then seeks to get relief from constant caregiving one or two weekends a month.

The article shows that socio-political positions, based on policy discourses about the caregiving father, equality between the sexes and the focus on children's needs, paradoxically can put pressure of responsibility on single mothers, not only for their children, but covering the parental responsibility of the father as well. Besides, the father, by withdrawing his support from the mother, can dominate her scope for action, not least because joint custody can enable him to deny the mother's relief through the contact family service.

But the contact family service can conduce to emancipation and increase single mothers' room for manoeuvre. In some cases in the study the fathers then have taken on more responsibility for contact with their children. A conclusion is that the contact family service provides not only a breathing space once or twice a month for single mothers, but also more independence and power, which has given the mothers a better position in negotiations, because they do not need the support from the father in the same way as before.

Margareta Regnér: När den goda viljan inte finns. Om frånvarande fäder i kontaktfamiljsinsatsen. 